\title{
Phenotypic diversity of Pseudoalteromonas citrea from different marine habitats and emendation of the description
}

\author{
Elena P. Ivanova, ${ }^{1,4}$ Elena A. Kiprianova, ${ }^{2}$ Valery V. Mikhailov, ${ }^{1}$ Galina F. \\ Levanova, ${ }^{3}$ Alexandra D. Garagulya, ${ }^{2}$ Nataliya M. Gorshkova, ${ }^{1}$ Mikhail V. \\ Vysotskii, ${ }^{5}$ Dan V. Nicolau, ${ }^{4}$ Noboru Yumoto, ${ }^{4}$ Takahisa Taguchi ${ }^{4}$ \\ and Susumu Yoshikawa ${ }^{4}$
}

Author for correspondence: Elena P. Ivanova (Russia address). Fax: +74232 314050. e-mail: ivep@piboc.marine.su

1,5 Pacific Institute of Bioorganic Chemistry', and Institute of Marine Biology5, Far-Eastern Branch of the Russian Academy of Sciences, 690022 Vladivostok, Pr. 100 Let Vladivostoku 159. Russia

2 Zabolotny Institute of Microbiology and Virology of the National Academy of Sciences, $252143 \mathrm{Kiev}$

Zabolotnogo St, 154, Ukraine

${ }^{3}$ Institute of Epidemiology and Microbiology, 603600 N. Novgorod, Russia

4 Osaka National Research Institute, AIST, Ikeda, Osaka 563, Japan
Four strains of marine, aerobic, agar-decomposing bacteria with one polar flagellum and with DNA G+C contents of 38.9-40.2 mol\% were isolated from the Far-Eastern mussels Crenomytilus grayanus and Patinopecten yessoensis. These four strains were identified as Pseudoalteromonas; however, they were phenotypically different from species described previously according to carbon compound utilization tests and the BIOLOG identification system. High agardecomposing activity was found in two strains, in one of which agarase, $\alpha$ galactosidase, pustulanase and laminarinase had been detected. The level of DNA homology of three of the strains was $70-100 \%$. The fourth isolate was genetically less related to the others (67\% DNA relatedness) and phenotypically was more distant from other members of this group; however, all four strains were assigned to a single species genotypically. DNA from the strains isolated from mussels showed $40-45 \%$ genetic relatedness with the DNA of Alteromonas atlantica, 8-36\% with DNA of Pseudoalteromonas haloplanktis subsp. haloplanktis, Pseudoalteromonas haloplanktis subsp. tetraodonis, Pseudoalteromonas undina, Pseudoalteromonas nigrifaciens and Pseudoalteromonas carrageenovora, 53 \% with Pseudoalteromonas elyakovii, $32-48 \%$ with marine $P$. nigrifaciens from mussels and $14-16 \%$ with Alteromonas macleodii. The DNA-DNA hybridization data revealed that the levels of relatedness between the strains isolated and the type strains of Pseudoalteromonas citrea and Pseudoalteromonas fuliginea described recently were significant (95-85\%). These results were confirmed by serological data employing polyclonal antibodies to cell surface antigens. The strains isolated from mussels were identified as $P$. citrea. The hybridization data showed that the name $P$. fuliginea Romanenko et al. 1994 should be recognized as a junior subjective synonym of $P$. citrea Gauthier 1977. A notable phenotypic diversity of $P$. citrea which might be a reflection of their ecological habitats is discussed.

Keywords: marine bacteria, Pseudoalteromonas citrea

\section{INTRODUCTION}

Intensive investigations of the genus Alteromonas during the last few years have led to revision and specification of its taxonomic structure on the one hand $(1,2,14,15,38)$, and broadening of the list of species on the other $(11,12,24,33)$. The resulting data from small-subunit rDNA sequence analysis (15) revealed that the genus Alteromonas should be re- stricted to a single species, Alteromonas macleodii, while a new genus, Pseudoalteromonas, was created for 13 other Alteromonas species. The latter are common inhabitants of the aquatic environment, and were isolated mainly from sea water $(8,14)$. Pseudoalteromonas strains, typically associated with marine animals $(16,29)$, might be of particular interest as a promising source for new species with distinct features. One such feature is a high hydrolytic activity, par- 
Table 1. List of strains studied

ATCC, American Type Culture Collection, Rockville, MD, USA; IAM, Institute of Molecular and Cellular Biosciences (formerly Institute of Applied Microbiology), University of Tokyo, Bunkyo-ku, Tokyo, Japan; KMM, Collection of Marine Microorganisms, Pacific Institute of Bioorganic Chemistry, Vladivostok, Russia; LMG, Collection of Bacteria of the Laboratory of Microbiology, University of Ghent, Gent, Belgium; NCIMB, National Collection of Industrial and Marine Bacteria, Aberdeen, UK; NCTC, National Collection of Type Cultures, London, UK. T, Type strain.

\begin{tabular}{|c|c|c|c|}
\hline Name & Strain & Other designations & Source \\
\hline $\begin{array}{l}\text { Pseudoalteromonas } \\
\text { citrea }\end{array}$ & KMM 157 & $2 \mathrm{GM} 20$ & This study \\
\hline $\begin{array}{l}\text { Pseudoalteromonas } \\
\text { citrea }\end{array}$ & KMM 188 & 32MA, VKPM B3907 & This study \\
\hline $\begin{array}{l}\text { Pseudoalteromonas } \\
\text { citrea }\end{array}$ & KMM 280 & 4GM5 & This study \\
\hline $\begin{array}{l}\text { Pseudoalteromonas } \\
\text { citrea }\end{array}$ & KMM 327 & 4GM7 & This study \\
\hline $\begin{array}{l}\text { Pseudoalteromonas } \\
\text { citrea }\end{array}$ & ATCC $29719^{\mathrm{T}}$ & & ATCC \\
\hline $\begin{array}{l}\text { Pseudoalteromonas } \\
\text { atlantica }\end{array}$ & KMM $655^{\mathrm{T}}$ & $\begin{array}{l}\text { IAM } 12376^{\mathrm{T}}, \text { IAM } \\
12927^{\mathrm{T}}, \mathrm{NCIMB}^{\mathrm{N}} 301^{\mathrm{T}}, \\
\text { ATCC } 19262^{\mathrm{T}}\end{array}$ & M. Akagawa-Matsushita \\
\hline $\begin{array}{l}\text { Pseudoalteromonas } \\
\text { aurantia }\end{array}$ & ATCC $33046^{\mathrm{T}}$ & & ATCC \\
\hline $\begin{array}{l}\text { Pseudoalteromonas } \\
\text { carrageenovora }\end{array}$ & KMM $656^{\mathrm{T}}$ & $\begin{array}{l}\text { IAM } 12662^{\mathrm{T}}, \text { ATCC } \\
43555^{\mathrm{T}}, \text { NCIMB } 302^{\mathrm{T}}\end{array}$ & M. Akagawa-Matsushita \\
\hline $\begin{array}{l}\text { Pseudoalteromonas } \\
\text { espejiana }\end{array}$ & ATCC $29659^{\mathrm{T}}$ & & ATCC \\
\hline $\begin{array}{l}\text { Pseudoalteromonas } \\
\text { haloplanktis subsp. } \\
\text { haloplanktis }\end{array}$ & $\mathrm{KMM} 460^{\mathrm{T}}$ & 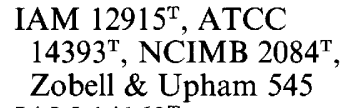 & U. Simidu \\
\hline $\begin{array}{l}\text { Pseudoalteromonas } \\
\text { haloplanktis subsp. } \\
\text { tetraodonis }\end{array}$ & $\mathrm{KMM} 458^{\mathrm{T}}$ & IAM $14160^{\mathrm{T}}$ & U. Simidu \\
\hline $\begin{array}{l}\text { Pseudoalteromonas } \\
\text { luteoviolacea }\end{array}$ & ATCC $33492^{\mathrm{T}}$ & & ATCC \\
\hline $\begin{array}{l}\text { Pseudoalteromonas } \\
\text { nigrifaciens }\end{array}$ & KMM $661^{\mathrm{T}}$ & $\begin{array}{l}\text { LMG } 2227^{\mathrm{T}}, \text { NCTC } \\
10691^{\mathrm{T}}, \text { ATCC } 23327^{\mathrm{T}}\end{array}$ & LMG \\
\hline $\begin{array}{l}\text { Pseudoalteromonas } \\
\text { nigrifaciens }\end{array}$ & KMM $662^{\mathrm{T}}$ & $\begin{array}{l}\text { IAM } 13010^{\mathrm{T}}, \text { ATCC } \\
19375^{\mathrm{T}}, \text { NCIMB } 8614^{\mathrm{T}}\end{array}$ & U. Simidu \\
\hline $\begin{array}{l}\text { Pseudoalteromonas } \\
\text { nigrifaciens }\end{array}$ & KMM 160 & $2 \mathrm{MC} 41$ & KMM \\
\hline $\begin{array}{l}\text { Pseudoalteromonas } \\
\text { nigrifaciens }\end{array}$ & KMM 156 & 2ML26 & KMM \\
\hline $\begin{array}{l}\text { Pseudoalteromonas } \\
\text { nigrifaciens }\end{array}$ & KMM 298 & 4ML18 & KMM \\
\hline $\begin{array}{l}\text { Pseudoalteromonas } \\
\text { undina }\end{array}$ & IAM $12922^{\mathrm{T}}$ & ATCC $29660^{\mathrm{T}}$ & M. Akagawa-Matsushita \\
\hline $\begin{array}{l}\text { Alteromonas } \\
\text { macleodii }\end{array}$ & KMM $568^{\mathrm{T}}$ & $\begin{array}{l}\text { ATCC } 27126^{\mathrm{T}}, \text { IAM } \\
12920^{\mathrm{T}}, \text { NCIMB } 1963^{\mathrm{T}}\end{array}$ & ATCC \\
\hline $\begin{array}{l}\text { Alteromonas } \\
\text { fuliginea }\end{array}$ & KMM $216^{\mathrm{T}}$ & $4-5$ & L. Romanenko \\
\hline $\begin{array}{l}\text { Alteromonas } \\
\text { distincta }\end{array}$ & $\mathrm{KMM} 638^{\mathrm{T}}$ & & L. Romanenko \\
\hline $\begin{array}{l}\text { Alteromonas } \\
\text { elyakovii }\end{array}$ & KMM $162^{\mathrm{T}}$ & 40MC, VKPM B3909 & KMM \\
\hline $\begin{array}{l}\text { Marinomonas } \\
\text { communis }\end{array}$ & ATCC $27118^{\mathrm{T}}$ & & ATCC \\
\hline Marinomonas vaga & $\operatorname{ATCC} 27119^{T}$ & & ATCC \\
\hline
\end{tabular}

ticularly in the degradation of an array of polysaccharides (1, 3). Agar-decomposing strains have been found among Vibrio spp. $(4,16)$, Cytophaga spp.
(37), Pseudomonas spp. $(42,43)$ and some actinomyces (18). Several years ago, Akagawa-Matsushita et al. (1) clarified a taxonomic assignment of a species 'Pseudo- 
monas atlantica', and described these agardecomposing bacteria as Alteromonas (now Pseudoalteromonas) atlantica.

The goal of the present study was to clarify and describe the taxonomic assignment of a group of both agar-digesting and non-agar-digesting unique Pseudoalteromonas strains isolated from the Far-Eastern mussels Crenomytilus grayanus and Patinopecten yessoensis.

\section{METHODS}

Bacterial strains and isolation procedure. The strains that we used are listed in Table 1. Mussels (Crenomytilus grayanus and Patinopecten yessoensis) were collected in 1985, 1989 and 1990 at the Pacific Institute Bioorganic Chemistry Marine Experimental Station, Troitza Bay, Gulf of Peter the Great, Sea of Japan. Mussels were collected at a depth of $8 \mathrm{~m}$ (salinity, $33 \%$, temperature, $12{ }^{\circ} \mathrm{C}$ ) and prepared aseptically. The strains were isolated from tissue homogenates by plating on marine agar 2216 (Difco) plates and on plates with medium $\mathrm{B}$, which contained $0.2 \%(\mathrm{w} / \mathrm{v})$ Bacto peptone (Difco), $0.2 \%(\mathrm{w} / \mathrm{v})$ casein hydrolysate (Merck), $0.2 \%(\mathrm{w} / \mathrm{v})$ Bacto yeast extract (Difco), $0.1 \%(\mathrm{w} / \mathrm{v})$ glucose, $0.002 \%$ (w/v) $\mathrm{KH}_{2} \mathrm{PO}_{4}, 0.005 \%$ (w/v) $\mathrm{MgSO}_{4} .7 \mathrm{H}_{2} \mathrm{O}$ and $1.5 \%$ $(\mathrm{w} / \mathrm{v})$ Bacto agar (Difco), $50 \%(\mathrm{v} / \mathrm{v})$ natural sea water and $50 \%(\mathrm{v} / \mathrm{v})$ distilled water at $\mathrm{pH} 7.5-7.8$ as described elsewhere (19). Strains were maintained on the same semi-solid $\mathrm{B}$ medium in tubes under mineral oil at $4{ }^{\circ} \mathrm{C}$. The strains were streaked on agar plates from tubes every 6 months to control purity and viability.

Phenotypic analysis. The phenotypic properties used for characterization of Pseudoalteromonas and related species have been described previously $(6,7,19,34)$. Electron micrographs of negatively stained cells were prepared with a JAM-7 electron microscope.

Nutritional tests. The tests for utilization of various organic substrates (listed in Table 2) as sole carbon sources at a concentration of $0.1 \%(\mathrm{w} / \mathrm{v})$ were performed in $10 \mathrm{ml}$ liquid BM medium (6) per tube. The bacteria were grown with shaking on a rotary shaker at 160 r.p.m. for $62 \mathrm{~h}$ at $26-28^{\circ} \mathrm{C}$. To test the bacterial oxidation of 95 carbon sources simultaneously, we used the BIOLOG technique. Strains were grown on marine agar plates at $28^{\circ} \mathrm{C}$ for $24 \mathrm{~h}$. Cell density was adjusted to $\mathrm{OD}_{590} 0.3 \pm 0.05$ in $0.4 \mathrm{M} \mathrm{NaCl}$ solution prepared with highly purified water. Three BIOLOG GN microplates for each strain were inoculated with $150 \mu \mathrm{l}$ of the cell suspension per well by means of a repeating pipetter. The inoculated plates were incubated at $28^{\circ} \mathrm{C}$. The results were read visually as recommended by Rüger \& Krambeck (32) after 1, 2, 3 and $5 \mathrm{~d}$ incubation.

A cluster analysis was performed using STATISTICA software (rel. 4.3 B, StatSoft 1993) for Windows. An unweighted pair group average method was used for cluster analysis, and a dendrogram was drawn by using a percentage disagreement method.

Genetic analysis. The DNA was isolated following the method of Marmur (27). The DNA $G+C$ content was determined by the thermal denaturation method of Marmur \& Doty (28). DNA-DNA hybridization was performed spectrophotometrically and initial renaturation rates were recorded as described by De Ley et al. (10) and Levanova et al. (26).
Serology. The strains were grown in liquid B medium with shaking for $24 \mathrm{~h}$ at $25^{\circ} \mathrm{C}$. Cells were harvested by centrifugation for $20 \mathrm{~min}$ at $10000 \mathrm{~g}$, washed twice and suspended in PBS $(137 \mathrm{mM} \mathrm{NaCl}, 2.7 \mathrm{mM} \mathrm{KCl}, 4.3 \mathrm{mM}$ $\mathrm{Na}_{2} \mathrm{HPO}_{4} .7 \mathrm{H}_{2} \mathrm{O}, 1.4 \mathrm{mM} \mathrm{KH}_{2} \mathrm{PO}_{4}, \mathrm{pH} 7 \cdot 3$ ) to a final density of $1 \times 10^{9}$ cells $\mathrm{ml}^{-1}$. Rabbit antiserum for the strains studied was prepared by immunization of rabbits with cells killed with $1 \%$ formaldehyde as described by Conway de Macario et al. (9). ELISA was performed by the methods of Voller $e t$ al. (39) and Karaulin et al. (21). The level of antigen relatedness was estimated as described by Conway de Macario et al. (9) as the mean value of three independent experiments.

Characterization of brown pigments. The features of brown melanin-like pigments were tested as described earlier (19). For production of pigment we used B medium (as described above) and BT medium which had the same composition plus L-tyrosine at $1 \mathrm{~g} \mathrm{l}^{-1}$. The synthetic $(\mathrm{S})$ medium contained $0.05 \mathrm{~g} \mathrm{KH}_{2} \mathrm{PO}_{4}, \quad 0.05 \mathrm{~g} \mathrm{~K}_{2} \mathrm{HPO}_{4}, \quad 0.05 \mathrm{~g} \mathrm{MgSO}_{4}, \quad 0.06 \mathrm{~g}$ $\mathrm{CuSO}_{4}, 0.05 \mathrm{~g} \mathrm{CaCl}_{2}, 20 \mathrm{mg}$ L-methionine, $20 \mathrm{mg}$ DL-tryptophan, $10 \mathrm{mg} \alpha$-asparagine, $10 \mathrm{mg}$ DL-phenylalanine, $2 \mathrm{~g}$

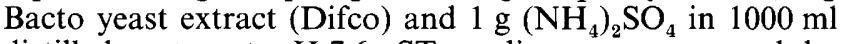
distilled water at $\mathrm{pH} 7 \cdot 6$. ST medium was prepared by adding $1 \%$ L-tyrosine to $\mathrm{S}$ medium. Inhibitors of melanogenesis, such as L-cysteine, EDTA and ascorbic acid, were added at $1-10 \mathrm{mM}$ if necessary.

Fatty acid analysis. The analysis of fatty acid methyl ethers was performed by GLC as described by Svetashev et al. (35).

\section{RESULTS AND DISCUSSION}

\section{Generic identification}

The four strains isolated (KMM 157, KMM 188, KMM 280 and KMM 327) were Gram-negative, strictly aerobic, rod-shaped bacteria with one polar flagellum (Fig. 1). None of the bacteria accumulated poly- $\beta$-hydroxybutyrate as an intracellular reserve product or had an arginine dihydrolase system. All were oxidase-positive, and all required $\mathrm{Na}^{+}$or sea water for growth. The DNA $\mathrm{G}+\mathrm{C}$ contents were $39 \cdot 2-40 \cdot 2 \mathrm{~mol} \%$. Cellular fatty acids were essentially the same as those of Pseudoalteromonas species (Table 5), and comprised 16:1(n-7), 16:0, 17:1 and $18: 1(n-7)$ fatty acids which were the most abundant. All these properties allowed us to assign the isolates from mussels to the genus Pseudoalteromonas.

\section{Physiological and biochemical characteristics}

The notable feature of the organisms studied was their phenotypic variability (Table 2). Strain KMM 188 produced a dark-brown pigment in all tested media (in particular at low temperatures), strain KMM 157 produced light-orange pigment in some media, and strains KMM 280 and 327 were colourless under ordinary conditions of cultivation. This fact led us to examine the formation of pigment on tyrosine-containing media that were optimal for melanogenesis and in media containing its inhibitors (cysteine, EDTA and ascorbic acid). We found that all four strains produced brown pigments on tyrosine-containing media and were colourless in the presence of inhibitors. The 
Table 2. Phenotypic features of $P$. citrea strains

+ , Positive; -, negative; ND, no data.

\begin{tabular}{|c|c|c|c|c|c|c|}
\hline Characteristic & $\operatorname{ATCC} 29719^{\mathrm{T} *}$ & KMM 188 & KMM 327 & KMM 280 & KMM 157 & $\begin{array}{l}\text { P. fuliginea } \\
\text { KMM } 216^{\mathrm{T}} \dagger\end{array}$ \\
\hline Polar flagellum & + & + & + & + & + & + \\
\hline Oxidase activity & + & + & + & + & + & + \\
\hline Pigmentation & Lemon-yellow & Black & - & - & Light-orange & $\begin{array}{l}\text { Blue-black or } \\
\text { brown }\end{array}$ \\
\hline $\mathrm{Na}^{+}$required for growth & + & + & + & + & + & + \\
\hline $\begin{array}{l}\text { Requirement for organic growth } \\
\text { factors }\end{array}$ & + & - & - & - & - & - \\
\hline \multicolumn{7}{|l|}{ Production of: } \\
\hline Agarase & - & + & - & - & + & + \\
\hline Gelatinase, amylase, lipase & + & + & + & + & + & + \\
\hline Chitinase & - & - & - & - & - & - \\
\hline Alginase & ND & + & + & ND & $\mathrm{ND}$ & + \\
\hline Levan & ND & + & + & + & + & ND \\
\hline \multicolumn{7}{|l|}{ Growth at: } \\
\hline $4{ }^{\circ} \mathrm{C}$ & - & + & - & - & - & + \\
\hline $10^{\circ} \mathrm{C}$ & ND & + & + & + & + & + \\
\hline $28^{\circ} \mathrm{C}$ & + & + & + & + & + & + \\
\hline $35^{\circ} \mathrm{C}$ & $+/-\ddagger$ & - & + & + & - & + \\
\hline $41^{\circ} \mathrm{C}$ & $+1-\ddagger$ & - & - & - & - & - \\
\hline \multicolumn{7}{|l|}{ Utilization of: } \\
\hline D-Glucose & + & + & + & + & - & - \\
\hline $\begin{array}{l}\text { D-Ribose, butyrate, ethanol, } \\
\text { propionate, aconitate, } \\
p \text {-hydroxybenzoate, phenylacetic } \\
\text { acid }\end{array}$ & ND & + & + & + & + & ND \\
\hline D-Xylose & ND & + & - & - & - & - \\
\hline D-Arabinose & - & - & - & - & - & - \\
\hline $\begin{array}{l}\text { D-Rhamnose, succinate, glycogen, } \\
\text { adonitol, aspartic acid, L-proline }\end{array}$ & ND & + & + & + & - & ND \\
\hline D-Mannose & + & + & + & + & - & - \\
\hline D-Galactose & ND & + & - & - & - & ND \\
\hline D-Fructose & + & + & + & + & + & ND \\
\hline Sucrose & - & + & - & - & + & - \\
\hline Trehalose & ND & + & - & - & + & ND \\
\hline Maltose & - & - & - & - & + & - \\
\hline Cellobiose, gluconate, acetate & - & + & + & + & - & ND \\
\hline Lactose, mannitol & - & + & + & + & + & - \\
\hline Salicin & - & - & + & - & - & ND \\
\hline Valerate & $\mathrm{ND}$ & - & - & - & + & $\mathrm{ND}$ \\
\hline Caproate & + & + & + & + & - & + \\
\hline Fumarate & - & - & + & + & - & ND \\
\hline$\alpha$-Glutarate & ND & - & - & - & - & $\mathrm{ND}$ \\
\hline DL-Lactate & - & - & + & - & + & ND \\
\hline Citrate & - & - & - & + & - & + \\
\hline 2-Oxoglutarate, L-histidine & - & - & - & - & - & ND \\
\hline Pyruvate & ND & - & + & + & + & ND \\
\hline Glycerol & - & + & - & + & - & ND \\
\hline Caprylic acid & ND & - & - & - & - & ND \\
\hline Pelargonic acid & ND & - & - & - & - & $\mathrm{ND}$ \\
\hline D-Sorbitol & - & + & + & - & + & ND \\
\hline Inositol & $\mathrm{ND}$ & - & - & - & + & $\mathrm{ND}$ \\
\hline L- $\alpha$-Alanine & - & + & - & - & + & ND \\
\hline L-Threonine & ND & + & - & - & + & ND \\
\hline
\end{tabular}


Table 2 (cont.)

\begin{tabular}{|c|c|c|c|c|c|c|}
\hline Characteristic & ATCC $29719^{\mathrm{T} *}$ & KMM 188 & KMM 327 & KMM 280 & КМM 157 & $\begin{array}{l}\text { P. fuliginea } \\
\text { KMM } 216^{\mathrm{T}} \dagger\end{array}$ \\
\hline Glutamic acid & - & + & + & + & + & ND \\
\hline L-Lysine, L-phenylalanine & ND & - & - & - & + & ND \\
\hline L-Arginine & - & + & + & + & + & + \\
\hline L-Ornithine & $\mathrm{ND}$ & + & - & + & + & ND \\
\hline L-Tyrosine & ND & - & + & + & + & + \\
\hline \multicolumn{7}{|l|}{ Susceptibility to: } \\
\hline Rifampicin $(15 \mu \mathrm{g})$ & ND & + & + & + & + & ND \\
\hline $\begin{array}{l}\text { Rhistomycin }(150 \mu \mathrm{m}) \text {, ampicillin } \\
(10 \mu \mathrm{g}), \text { neomycin }(15 \mu \mathrm{g})\end{array}$ & $\mathrm{ND}$ & - & - & - & - & ND \\
\hline $\begin{array}{l}\text { Kanamycin }(10 \mu \mathrm{g}), \text { streptomycin } \\
(15 \mu \mathrm{g})\end{array}$ & + & - & - & - & - & ND \\
\hline $\begin{array}{l}\text { Benzylpenicillin }(10 \mu \mathrm{g}) \\
\text { lincomycin }(10 \mu \mathrm{g})\end{array}$ & - & - & - & - & - & $\mathrm{ND}$ \\
\hline $\begin{array}{l}\text { Erythromycin }(15 \mu \mathrm{g}) \text {, gentamicin } \\
(10 \mu \mathrm{g}) \text {, oxacillin }(20 \mu \mathrm{g})\end{array}$ & + & + & + & + & + & ND \\
\hline Cephalexin $(10 \mu \mathrm{g})$ & - & - & - & - & - & ND \\
\hline Polymyxin $(50 \mu \mathrm{g})$ & ND & + & + & + & - & ND \\
\hline Ofloxacin $(10 \mu \mathrm{g})$ & + & + & + & + & - & ND \\
\hline
\end{tabular}

* Data from (13) and (14).

$\dagger$ Data from (30).

$\$ 11-89 \%$ of strains are positive.



Fig. 1. Electron micrograph of $P$. citrea KMM 188. Bar, $1 \mu \mathrm{m}$.

pigments were not extractable with water, alcohols or various polar solvents but were extracted from cells with a $0.5 \mathrm{M} \mathrm{NaOH}$ aqueous solution. The pigment extracted in alkaline solution behaved qualitatively as melanin: it became colourless upon addition of $\mathrm{H}_{2} \mathrm{O}_{2}$, whereas the addition of $\mathrm{KMnO}_{4}$ gave a green colour. The absorption maxima of the pigment at 225 and $273 \mathrm{~nm}$ were nearly the same as those for synthetic melanin (Sigma), namely 223 and $269 \mathrm{~nm}$. The IR spectrum of the pigment had peaks at 1.714, 1.702, 
Table 3. DNA relatedness among tested strains

\begin{tabular}{|c|c|c|c|c|c|c|c|}
\hline \multirow[t]{2}{*}{ Organism } & \multirow{2}{*}{$\begin{array}{c}\mathrm{G}+\mathrm{C} \\
\text { content } \\
(\mathrm{mol} \%)\end{array}$} & \multicolumn{6}{|c|}{ Percentage hybridization with DNA from: } \\
\hline & & $\begin{array}{l}\text { P. citrea } \\
\text { ATCC } \\
29719^{\mathrm{T}}\end{array}$ & KMM 188 & KMM 157 & KMM 280 & KMM $216^{\mathrm{T}}$ & $\begin{array}{l}\text { P. elyakovit } \\
\text { KMM } 162^{\mathrm{T}}\end{array}$ \\
\hline P. citrea ATCC $29719^{\mathrm{T}}$ & $42 \cdot 1$ & 100 & & 95 & & 92 & \\
\hline P. citrea KMM 188 & $39 \cdot 2$ & & 100 & & 67 & & \\
\hline P. citrea $\mathrm{KMM} 157$ & $40 \cdot 0$ & & 67 & 100 & & 85 & \\
\hline P. citrea KMM 280 & $40 \cdot 0$ & & 70 & & 100 & & \\
\hline P. citrea KMM 327 & $39 \cdot 8$ & & & & 100 & & \\
\hline P. atlantica ATCC $19262^{\mathrm{T}}$ & $39 \cdot 2$ & & & 40 & 45 & & \\
\hline P. aurantia ATCC $33046^{\mathrm{T}}$ & $42 \cdot 8$ & 52 & & 61 & & 55 & \\
\hline P. carrageenovora IAM $12662^{\mathrm{T}}$ & $39 \cdot 2$ & & 36 & & & & \\
\hline $\begin{array}{l}\text { P. haloplanktis subsp. } \\
\text { haloplanktis IAM } 12915^{\mathrm{T}}\end{array}$ & $40 \cdot 2$ & & & 42 & 10 & & \\
\hline $\begin{array}{l}\text { P. haloplanktis subsp. } \\
\text { tetraodonis } \mathrm{IAM} 14160^{\mathrm{T}}\end{array}$ & $36 \cdot 1$ & & 10 & & 8 & & \\
\hline P. nigrifaciens IAM $13010^{\mathrm{T}}$ & $39 \cdot 2$ & & 24 & & 8 & & \\
\hline P. nigrifaciens KMM 156 & $39 \cdot 2$ & & 48 & & 42 & & 31 \\
\hline P. nigrifaciens KMM 298 & $39 \cdot 5$ & & 33 & & & & \\
\hline P. nigrifaciens $\mathrm{KMM} 160$ & $39 \cdot 3$ & & & & 32 & & 37 \\
\hline P. undina IAM $12922^{\mathrm{T}}$ & $42 \cdot 2$ & & 24 & 16 & & & \\
\hline A. macleodii ATCC $27126^{\mathrm{T}}$ & $44 \cdot 4$ & & & 16 & 14 & & \\
\hline P. fuliginea $\mathrm{KMM} 216^{\mathrm{T}}$ & $43 \cdot 8$ & & & & & 100 & \\
\hline P. distincta $\mathrm{KMM} 638^{\mathrm{T} *}$ & $43 \cdot 8$ & & & & & 41 & \\
\hline P. elyakovii KMM $162^{\mathrm{T}}$ & 38.9 & & & & 53 & & \\
\hline
\end{tabular}

* Data from (31).

$1.672,1.624,1 \cdot 510,1 \cdot 486,1.402$ and $1.024 \mathrm{~cm}^{-1}$. All the data confirmed the pigments as melanin.

Strains KMM 188 and 157 hydrolysed agar, whereas strains KMM 280 and 327 did not show agarolytic activity. There is one agar-decomposing member of the Pseudoalteromonas genus, $P$. atlantica, but strains isolated from mussels were distant from this species in their phenotypic properties and level of DNA homology (see below). Recently, a few new species of Alteromonas, Alteromonas fuliginea (30), Alteromonas distincta (31) and Alteromonas elyakovii (20), have been described. In accordance with the phylogenetic analysis of the genus Alteromonas (15) that resulted in the creation of a new genus, Pseudoalteromonas, for the members of the 'Alteromonas haloplanktis' rRNA cluster, the species mentioned should be considered as representatives of the Pseudoalteromonas genus. The bacteria referred to as Pseudoalteromonas fuliginea were capable of agar hydrolysis, and included four conspecific strains with the levels of relatedness ranged from $90 \%$ to $96 \%$, and the DNA G +C contents in the range $41.5-43.8 \mathrm{~mol} \%$. The bacteria were isolated from Far-Eastern invertebrates, namely ascidians Halocynthia aurantium, Amaraucium translucidum and sponge Plocamia sp., inhabiting littoral zones of the Sea of Japan, and the Commandorskie Islands. The isolates of $P$. fuliginea had many of the same physiological and morphological characteristics as strain
KMM 188 (same pigment; hydrolysis of agar, gelatin, starch, alginate). However, they differed from strain KMM 188 in their lack of ability to use certain carbon substrates (D-glucose, D-xylose, sucrose, lactose, citrate, mannitol), and higher values of the DNA G $+C$ contents (30). A new bacterium belonging to Pseudoalteromonas distincta that was isolated from an unidentified species of sponge collected near the Commander Islands produced melanin-like pigment, though it differed from all Pseudoalteromonas species described previously in its flagellation, its lack of ability to hydrolyse biomacromolecules (agar, starch, chitin, alginate, carrageenan), and its use of an array of carbon sources except citrate (31). The last species among those newly described, Pseudoalteromonas elyakovii, was assigned to a non-pigmented bacterium isolated from the mussel Crenomytilus grayanus (20). Several distinctive phenotypic characteristics of $P$. elyakovii are included in Table 4.

The nutritional spectra of the strains studied, particularly of KMM 157, are rather diverse. Strain KMM 157 differs from the other three members of the group by its ability to utilize 15 different carbon sources. At the same time, the BIOLOG technique based on bacterial oxidation of 95 carbon sources has shown a close similarity between strains KMM 188 and 157 . According to metabolic profiles obtained, strains KMM 188 and 157 were clearly distinguished from 
Table 4. Differential characteristics of Pseudoalteromonas spp.

For all tests $n=8$, except for cellobiose, D-gluconate, pyruvate, fumarate, glycerol and rhamnose where $n=4 ;+$, positive; - , negative; ND, no data available; $+/-, 11-89 \%$ of the strains are positive.

\begin{tabular}{|c|c|c|c|c|c|c|c|c|c|c|c|c|c|c|c|c|}
\hline & $\begin{array}{c}P . \\
\text { citrea }^{*}\end{array}$ & $\begin{array}{c}P . \\
\text { citrea } \\
\text { ATCC } \\
29719^{\mathrm{T}} \dagger\end{array}$ & $\begin{array}{c}P . \\
\text { elyakovii } \\
\text { KMM } \\
16^{T_{+}}+\end{array}$ & $\begin{array}{c}P . \\
\text { distincta } \\
\text { KMM } \\
6^{\mathrm{T}} \mathrm{\gamma} \S\end{array}$ & $\begin{array}{c}P . \\
\text { haloplanktis } \\
\text { subsp. } \\
\text { haloplanktis } \\
\text { IAM } \\
12915^{\mathrm{T}} \|\end{array}$ & $\begin{array}{c}P . \\
\text { haloplanktis } \\
\text { subsp. } \\
\text { tetraodonis } \\
\text { IAM } \\
\text { 14160 }^{\mathrm{T}} \|\end{array}$ & $\begin{array}{c}P . \\
\text { atlantica } \\
\text { IAM } \\
\text { 12975 }^{\mathrm{T}} \|\end{array}$ & $\begin{array}{c}P . \\
\text { carrageenovora } \\
\text { IAM } \\
12662^{\mathrm{T}} \|\end{array}$ & $\begin{array}{c}P . \\
\text { espejiana } \\
\text { IAM } \\
12640^{\mathrm{T}} \|\end{array}$ & $\begin{array}{c}P . \\
\text { undina } \\
\text { IAM } \\
\text { 12922 }^{\mathrm{T}} \|\end{array}$ & $\begin{array}{c}P . \\
\text { rubra } \\
\text { ATCC } \\
\text { 29580 }^{\text {te }}\end{array}$ & $\begin{array}{c}P . \\
\text { luteoviolacea } \\
\text { ATCC } \\
\text { 33492 }^{\text {To }}\end{array}$ & $\begin{array}{c}P . \\
\text { aurantia } \\
\text { ATCC } \\
33046^{\top 9}\end{array}$ & $\begin{array}{c}P . \\
\text { piscicida } \\
\text { ATCC }^{\mathrm{TTC}} \\
\text { 15251 }^{\mathrm{T} * *}\end{array}$ & $\begin{array}{c}P . \\
\text { denitrificans } \\
\text { ATCC } \\
\mathbf{4 3 3 3 7}^{r}+\dagger\end{array}$ & $\begin{array}{c}P . \\
\text { nigrifaciens } \\
\text { ATCC } \\
\text { 19375 }^{\top} \|\end{array}$ \\
\hline Pigments & 75 & + & - & + & - & - & - & - & - & - & + & + & + & + & + & + \\
\hline $\begin{array}{l}\text { Denitrification } \\
\text { with gas } \\
\text { formation } \\
\text { Hydrolysis of: }\end{array}$ & 0 & - & - & - & - & - & - & - & - & - & - & - & - & - & + & - \\
\hline Starch & 100 & + & + & - & - & - & + & - & + & + & + & + & + & + & + & + \\
\hline Chitin & 0 & - & - & - & - & - & - & - & - & + & - & - & - & & + & - \\
\hline Agar & 75 & - & - & - & - & - & + & - & - & - & - & - & - & - & - & - \\
\hline Alginate & 100 & ND & + & - & & & & & & & & & & & & \\
\hline \multicolumn{17}{|l|}{ Growth at: } \\
\hline $4^{\circ} \mathrm{C}$ & 63 & - & + & + & - & - & - & + & - & + & - & $+/-$ & + & & + & $+1-$ \\
\hline $35^{\circ} \mathrm{C}$ & 75 & + & + & + & + & + & + & + & + & + & + & + & - & + & - & $+1-$ \\
\hline \multicolumn{17}{|l|}{ Utilization of: } \\
\hline D-Glucose & 38 & + & + & - & + & + & + & + & + & + & + & + & + & ND & + & + \\
\hline D-Mannose & 38 & + & - & - & - & - & + & - & - & - & + & - & + & + & & + \\
\hline D-Fructose & 100 & + & + & $\mathrm{ND}$ & + & - & + & + & + & - & - & - & + & + & & + \\
\hline Sucrose & 25 & - & - & - & - & + & + & + & + & + & - & - & - & + & - & + \\
\hline Maltose & 13 & - & - & - & + & + & & & + & + & - & + & $+1-$ & & + & + \\
\hline Cellobiose & 75 & - & - & $\mathrm{ND}$ & - & - & + & + & $+1-$ & - & - & - & - & & & $+1-$ \\
\hline Lactose & 50 & - & + & - & - & + & + & + & + & - & - & - & - & & - & $+1-$ \\
\hline D-Gluconate & 75 & - & - & ND & - & + & & & - & - & - & - & - & & - & $+/-$ \\
\hline Pyruvate & 75 & - & + & $\mathrm{ND}$ & + & + & + & - & + & - & - & - & & & + & + \\
\hline Fumarate & 50 & - & - & $\mathrm{ND}$ & + & + & + & + & + & - & - & - & - & & - & - \\
\hline Glycerol & 50 & - & - & ND & - & - & + & + & - & - & - & - & - & - & & $+1-$ \\
\hline Rhamnose & 75 & ND & - & ND & - & - & - & - & - & - & & & & - & & $+1-$ \\
\hline Citrate & 63 & - & - & + & + & - & + & + & + & - & - & - & - & + & & - \\
\hline
\end{tabular}

* Values are the percentages of strains that exhibit positive reactions.

$\dagger$ Data from (13) and (14).

$¥$ Data from (20).

$\S$ Data from (31).

| Data from (1).

T Data from (14).

** Data from (17).

$\dagger \dagger$ Data from (12).

other species of related marine bacteria. The type strains of Marinomonas vaga and Marinomonas communis, which have been proven to be far-related to Alteromonas/Pseudoalteromonas species by rRNADNA hybridization (38), proved to be distant from the type strains of Pseudoalteromonas phenotypically. In contrast, the type strain of $A$. macleodii was phenotypically close to Pseudoalteromonas spp., especially Pseudoalteromonas haloplanktis subsp. tetraodonis. Because of the high phenotypic variability of Alteromonas-related bacteria, we consider the application of metabolic fingerprints is limited for species discrimination.

\section{DNA relatedness}

The levels of DNA relatedness of strains isolated from mussels and some type species of Pseudoalteromonas are presented in Table 3. The level of DNA homology of three of the strains was 70-100\%. The fourth isolate was genetically less related to the others $(67 \%$ DNA relatedness) and phenotypically was more distant from other members of this group; however, all four strains were assigned to a single species genotypically (39). Their genetic similarity with the type strain of $P$. atlantica was $40-45 \%$, with $P$. elyakovii was $53 \%$, with marine Pseudoalteromonas nigrifaciens from mussels was 32-48\%, with other Pseudoalteromonas type strains was $8-36 \%$ and with $A$. macleodii was 14-16\%. Since the DNA relatedness value between $P$. fuliginea and $P$. distincta was $41 \%(30)$, the latter species represents a distinct taxon. In contrast, the levels of DNA-DNA homology among the type strain Pseudoalteromonas citrea, $P$. fuliginea and the four strains from mussels were $85-95 \%$. These results strongly suggest that the bacteria inside this phenotypically diverse group are closely related genetically; therefore the recently described species $P$. fuliginea 
Table 5. Cellular fatty acid composition of $P$. citrea strains

\begin{tabular}{|c|c|c|c|c|}
\hline Fatty acid & ATCC $29719^{\mathrm{T}}$ & KMM 188 & KMM 157 & KMM 216 \\
\hline $11: 0-3-\mathrm{OH}$ & $0 \cdot 18$ & $0 \cdot 10$ & $0 \cdot 10$ & 0.21 \\
\hline $12: 0-3-\mathrm{OH}$ & 1.09 & $1 \cdot 24$ & 1.73 & 1.97 \\
\hline $12: 0$ & 0.79 & $1 \cdot 02$ & $1 \cdot 13$ & 1.05 \\
\hline $12: 1$ & 0.60 & $1 \cdot 10$ & 0.60 & 1.30 \\
\hline iso- $13: 0$ & 0.00 & 0.00 & 0.00 & 0.00 \\
\hline $13: 0$ & $0 \cdot 31$ & 0.00 & 0.00 & 0.00 \\
\hline $13: 1$ & $0 \cdot 15$ & 0.17 & $0 \cdot 10$ & 0.31 \\
\hline iso- $14: 0$ & $0 \cdot 20$ & 0.00 & 0.00 & 0.00 \\
\hline $14: 0$ & $3 \cdot 10$ & 0.84 & 1.27 & 0.85 \\
\hline $14: 1(n-7)$ & 0.99 & 0.65 & 0.81 & 0.36 \\
\hline iso- $15: 0$ & $0 \cdot 10$ & 0.00 & 0.00 & 0.00 \\
\hline anteiso- $15: 0$ & 0.54 & 0.27 & 0.13 & 0.42 \\
\hline $15: 0$ & 2.98 & $2 \cdot 14$ & 1.05 & 2.64 \\
\hline $15: 1(n-6)$ & $0 \cdot 19$ & $0 \cdot 17$ & 0.00 & 0.30 \\
\hline $15: 1(n-8)$ & $3 \cdot 80$ & 1.04 & 0.43 & $1 \cdot 16$ \\
\hline iso- $16: 0$ & $2 \cdot 12$ & 0.68 & $1 \cdot 10$ & 1.20 \\
\hline $16: 0$ & 21.24 & 33.08 & 29.65 & 26.80 \\
\hline $16: 1(n-5)$ & 0.52 & 0.39 & 0.00 & 0.00 \\
\hline $16: 1(n-7)$ & $41 \cdot 20$ & $45 \cdot 10$ & $43 \cdot 24$ & $\mathbf{4 4 \cdot 4 1}$ \\
\hline $16: 1(n-9)$ & 1.63 & 1.01 & 0.87 & 1.20 \\
\hline iso- $17: 0$ & 0.37 & 0.29 & $0 \cdot 17$ & 0.28 \\
\hline anteiso-17:0 & 0.31 & 0.31 & 0.38 & 1.21 \\
\hline $17: 0$ & 1.57 & $2 \cdot 13$ & 1.21 & $2 \cdot 70$ \\
\hline $17: 1(n-6)$ & 0.55 & $0 \cdot 11$ & $0 \cdot 15$ & 0.23 \\
\hline $17: 1(n-8)$ & $6 \cdot 44$ & 2.96 & 3.41 & 5.73 \\
\hline iso- $18: 0$ & $0 \cdot 12$ & $0 \cdot 14$ & $0 \cdot 15$ & 0.23 \\
\hline $18: 0$ & 0.52 & 1.34 & $1 \cdot 13$ & $1 \cdot 19$ \\
\hline $18: 1(n-7)$ & 7.09 & $2 \cdot 78$ & $10 \cdot 02$ & 3.20 \\
\hline $18: 1(n-9)$ & 0.24 & 0.37 & 0.33 & 0.29 \\
\hline $18: 1(n-11)$ & 0.00 & 0.00 & 0.00 & 0.00 \\
\hline $19: 1$ & 0.13 & 0.00 & $0 \cdot 14$ & 0.00 \\
\hline Total & 99.67 & 99.99 & $99 \cdot 84$ & 99.81 \\
\hline
\end{tabular}

together with the bacteria studied here should be placed in the same species, $P$. citrea. We propose that the name $P$. fuliginea Romanenko et al. 1994 should be rejected because it is a junior subjective synonym of $P$. citrea Gauthier 1977.

\section{Serology}

The results of the DNA-DNA hybridization experiments were supported by serological data employing polyclonal antibodies to cell surface determinants. Antiserum to strains KMM 188 and KMM 157 did not discernibly react with surface antigens of $P$. atlantica, Pseudoalteromonas piscicida, $P$. haloplanktis subsp. haloplanktis, $P$. haloplanktis subsp. tetraodonis, Pseudoalteromonas nigrifaciens, Pseudoalteromonas carrageenovora, Pseudoalteromonas luteoviolaceae, Pseudoalteromonas undina and Pseudoalteromonas espejiana, showing $22-34 \%$ and $15-30 \%$ of surface antigen similarity, respectively. The same values increased up to $60 \%$ for $P$. citrea and $48 \%$ for Pseudoalteromonas aurantia.

\section{Description of $\boldsymbol{P}$. citrea strains}

Our present data provide evidence that the strains studied belong to $P$. citrea, although we cannot yet find an explanation for their essential phenotypic differences. Originally three strains of marine bacteria isolated from the surface of water (Mediterranean Sea) that produced a lemon-yellow, non-carotenoid pigment and a polyanionic antibiotic substance have been assigned to $P$. citrea (13). The bacteria studied here, and referred to as $P$. fuliginea, were isolated from other natural econiches, namely molluscs, ascidians and sponges from the Sea of Japan and the Bering Sea, and were distinguished by their great phenotypic variability. The strains mentioned were able to synthesize a variety of pigments, had unique hydrolytic activity, and the ability to use an array of carbon substrates (Table 3 and 4). For example, the enzyme activities of strain KMM 188 were studied using a set of carbohydrates including some algal polysaccharides (5). Agarase, $\alpha$-galactosidase, pustulanase and laminarinase, enzymes that hydrolyse the brown algal $1,6-\beta$ and $1,3-\beta$ glucans, have been found. It is 
noteworthy that the activity of $\alpha$-galactosidase was 20 times stronger than agarase. We assume that the effective hydrolysis of agar-agar by strain KMM 188 was due to the additive effect of agarase and $\alpha$ galactosidase probably produced at different growth phases (5). Compared to the type species $P$. citrea these organisms did not inhibit the growth of Gram-positive bacteria and fungi, but proved to have the antibiotic effect against enterobacteria and Pseudomonas (23). The fatty acid composition of a type strain and the bacteria associated with marine invertebrates was characteristic for the genus (Table 5). However, it is of interest to note that a few minor fatty acids (13:0 and iso-14:0) were detected only for the type strain, and the amount of 14:0,15:1(n-8) and iso-16:0 fatty acids was as much as two to three times more than that of the bacteria studied here, but the amount of palmitic acid $(16: 0)$ of the type strain was lower than that of other bacteria belonging to the same species. It is clear that the species $P$. citrea comprises a diverse group of bacteria isolated from various marine environments. We believe that the phenotypic variations are a reflection of different ecological niches. We propose the term 'ecosubspecies' for the Far-Eastern strains of P. citrea.

\section{Emended description of Pseudoalteromonas citrea Gauthier 1977}

Pseudoalteromonas citrea (cit're.a. L. adj. citreus lemon-yellow).

Cells are Gram-negative, strictly aerobic, motile with one polar flagellum, straight rods or rod-shaped, $0.5-0.8 \times 1.0-1.5 \mu \mathrm{m}$ in exponential growth phase. None of the strains produced endospores or capsules. Produces cellular lemon-yellow, non-carotenoid, lightorange or melanin-like pigments depending on medium composition and culture conditions. Sodium ions are essential for growth; the optimum growth occurs with concentrations of $0.5-0.6 \mathrm{M} \mathrm{Na}^{+}$. Amino acids are not required for growth. Temperature range for growth is $4-40^{\circ} \mathrm{C}$. Most rapid growth occurs at $28^{\circ} \mathrm{C}$. The optimum $\mathrm{pH}$ values are from 6.0 to 12 . Chemoorganotrophs; metabolism is strictly respiratory. Positive for hydrolysis of starch, Tween 80 , casein and gelatin; some strains hydrolyse levan, alginate, agar-agar, pustulan and laminarin. Chitin and aesculin are not hydrolysed. Positive for oxidase, some strains for catalase. Negative for nitrate reduction, denitrification and luminescence. Glucose, ribose, rhamnose, mannose, fructose, propionate, butyrate, caproate, ethanol, $p$-hydroxybenzoate, phenylacetic acid, L-arginine and L-tyrosine are utilized as sole sources of carbon and energy. The following compounds are not utilized: arabinose, maltose, sucrose, $\alpha$-glutarate, 2 -oxoglutarate, glycerol, citrate, caprylic acid, pelargonic acid and L-histidine. The strains are sensitive to rifampicin, ampicillin, gentamicin, oxacillin, polymyxin, erythromycin and ofloxacin. The main fatty acids of the cells are palmitoleic, palmitic and cis-vaccenic acids. Some strains produce polyanionic, autotoxic antibiotics on complex media. The DNA G + C content is 38.9-44.7 mol\%. Strains have been isolated from the surface sea water of the Mediterranean Sea and from mussels, ascidians and sponges collected from the Sea of Japan and the Bering Sea. The type strain is ATCC 29719.

\section{ACKNOWLEDGEMENTS}

This study was supported by a Fellowship from the Foreign Researcher Invitation Program of the Agency of Industrial Science and Technology of Japan, by funds from the Russian Fund for Basic Research, 96-04-49058, and by a grant of the State Committee for Science and Technologies of the Russian Federation, 96-03-19/97-03-19. The expert assistance of $\mathrm{Dr}$ A. M. Lysenko, Dr I. Bakunina and $\mathrm{Dr}$ N. Utkina was greatly appreciated.

\section{REFERENCES}

1. Akagawa-Matsushita, M., Matsuo, M., Koga, Y. \& Yamasato, K. (1992). Alteromonas atlantica sp. nov. and Alteromonas carrageenovora sp. nov., bacteria that decomposed algal polysaccharides. Int J Syst Bacteriol 42, 621-627.

2. Akagawa-Matsushita, M., Koga, Y. \& Yamasato, K. (1993). DNA relatedness among nonpigmented species of Alteromonas and synonymy of Alteromonas haloplanktis (ZoBell and Upham 1944) Reichelt and Baumann 1973 and Alteromonas tetraodonis Simidu et al. 1990. Int J Syst Bacteriol 43, 500-503.

3. Andrykovitch, G. \& Marx, I. (1988). Isolation of a new polysaccharide-digesting bacterium from a salt marsh. Appl Environ Microbiol 54, 1061-1062.

4. Aoki, T., Araki, T. \& Kitamikado, M. (1990). Purification and characterization of $\beta$-agarase from Vibrio sp. AP-2. Bull Jpn Soc Sci Fish 56, 825-830.

5. Bakunina, I. Yu., Ivanova, E. P., Nedashkovskaya, O. I., Gorshkova, N. M., Elyakova, L. A. \& Mikhailov, V. V. (1996). Search for $\alpha$-galactosidase producers among marine bacteria of the genus Alteromonas. Prikl Biokhim Mikrobiol 32, 624-628 (in Russian).

6. Baumann, L., Baumann, P., Mandel, M. \& Allen, R. D. (1972). Taxonomy of aerobic marine eubacteria. $J$ Bacteriol 110, 402-429.

7. Baumann, P. \& Baumann, L. (1981). The marine Gramnegative eubacteria; genera Photobacterium, Beneckea, Alteromonas, Pseudomonas, and Alcaligenes. In The Prokaryotes. A Handbook on Habitats, Isolation, and Identification of Bacteria, 1st edn, vol. 2, pp. 1302-1330. Edited by M. P. Starr, H. Stolp, H. G. Trüper, A. Balows \& H. G. Schlegel. Berlin: Springer.

8. Baumann, P., Gauthier, M. J. \& Baumann, L. (1984). Genus Alteromonas. Baumann, Baumann, Mandel and Allen 1972, 418. In Bergey's Manual of Systematic Bacteriology, vol. 1, pp. 343-354. Edited by N. R. Krieg \& J. G. Holt. Baltimore: Williams \& Wilkins.

9. Conway de Macario, E., Macario, A. J. L. \& Wolin, M. J. (1982). Specific antisera and immunological procedures for characterization of methanogenic bacteria. J Bacteriol 149 , $320-328$.

10. De Ley, J., Cattoir, H. \& Reynaerts, A. (1970). The quantitative measurement of DNA hybridization from renaturation rates. Eur J Biochem. 12, 133-142.

11. De Vos, P., Van Landschoot, A., Segers, P. \& 9 other authors 
(1989). Genotypic relationships and taxonomic localization of unclassified Pseudomonas and Pseudomonase-like strains by deoxyribonucleic acid:ribosomal ribonucleic acid hybridization. Int J Syst Bacteriol 39, 35-49.

12. Enger, O., Nygaard, H., Solberg, M., Schel, G., Nielsen, J. \& Dundas, I. (1987). Characterization of Alteromonas denitrificans sp. nov. Int J Syst Bacteriol 37, 416-421.

13. Gauthier, M. J. (1977). Alteromonas citrea, a new Gramnegative, yellow-pigmented species from seawater. Int $J$ Syst Bacteriol 27, 349-354.

14. Gauthier, M. J. \& Breittmayer, V. A. (1992). The genera Alteromonas and Marinomonas. In The Prokaryotes, 2nd edn, vol. 3, pp. 3046-3070. Edited by A. Balows, H. G. Trüper, M. Dworkin, W. Harder \& K.-H. Schleifer. New York: Springer.

15. Gauthier, G., Gauthier, M. \& Christen, R. (1995). Phylogenetic analysis of the genera Alteromonas, Shewanella, and Moritella using genes coding for small-subunit rRNA sequences and division of the genus Alteromonas into two genera, Alteromonas (emended) and Pseudoalteromonas gen. nov., and twelve new species combinations. Int $J$ Syst Bacteriol 45, 755-761.

16. Grimes, D. J., Brayton, P., Colwell, R. R. \& Gruber, S. H. (1985). Vibrios as autochtonous flora of neritic sharks. Syst Appl Microbiol 6, 221-226.

17. Hansen, A. J., Weeks, O. B. \& Colwell, R. R. (1965). Taxonomy of Pseudomonas piscicida (Bein) Buck, Meyers, and Leifson. $J$ Bacteriol 89, 752-761.

18. Humm, H. J. (1946). Marine agar-digesting bacteria of the south Atlantic coast. Bull Duke Univ Mar Lab 3, 43-75.

19. Ivanova, E. P., Kiprianova, E. A., Mikhailov, V. V., Levanova, G. F., Garagulya, A. D., Gorshkova, N. M., Yumoto, N. \& Yoshikawa, S. (1996). Characterization and identification of marine Alteromonas nigrifaciens strains and emendation of the description. Int J Syst Bacteriol 46, 223-228.

20. Ivanova, E. P., Mikhailov, V. V., Kiprianova, E. A., Levanova, G. F., Garagulya, A. D., Frolova, G. M. \& Svetashev, V. I. (1996). Alteromonas elyakovii sp. nov., a new bacterium isolated from marine mollusks. Biol Morya 22, 231-237 (in Russian).

21. Karaulin, A. Yu., Dzantiev, B. B., Orlova, G. G. \& Egorov, A. M. (1990). Some ELISA peculiarities of the bacterial cells. Mikrobiol J (Ukrine) 9, 12-18 (in Russian).

22. Kelley, S. K., Coyne, V. E., Sledjeski, W. C., Fugua, R. M. \& Weiner, R. M. (1990). Identification of a tyrosine from a prophetic marine bacterium. FEMS Microbiol Lett 67, 275-280.

23. Kiprianova, E. A., Ivanova, E. P., Levanova, G. F., Garagulya, A. D. \& Smirnov, V. V. (1996). Microorganisms of Pseudoalteromonas genus isolated from marine mussels. Mikrobiol $J$ (Ukrine) 58, 3-11 (in Russian).

24. Kodama, K., Shiozawa, H. \& Ishi, A. (1993). Alteromonas rava sp. nov., a marine bacterium that produces a new antibiotic, thiomarinol. Annu Rep Sankyo Res Lab 45, 131-136.

25. Lee, J. V., Gibson, D. M. \& Shewan, J. M. (1981). Alteromonas putrefaciens sp. nov. Validation list no. 6. Int $J$ Syst Bacteriol 31, 215-218.

26. Levanova, G. F., Novova, E. V., Sorokina, V. N. \& Kiprianova, E. A. (1984). Spectrophotometric method of DNA-DNA molecular hybridization for bacteria of the genus Pseudomonas. Biol Sci 8, 27-32 (in Russian).
27. Marmur, J. (1961). A procedure for the isolation of deoxyribonucleic acid from microorganisms. $J \mathrm{Mol} B i o l ~ 3$, 208-218.

28. Marmur, J. \& Doty, P. (1962). Determination of the base composition of deoxyribonucleic acid from its thermal denaturation temperature. J Mol Biol 5, 109-118.

29. Nair, S., Kita-Tsukamoto, K. \& Simidu, U. (1988). Bacterial flora of healthy and abnormal chaetognaths. Bull Jpn Soc Sci Fish 54, 491-496.

30. Romanenko, L. A., Lysendo, A. M., Mikhailov, V. V. \& Kurika, A. V. (1994). A new species of brown-pigmented agarolytic bacteria of the genus Alteromonas. Mikrobiologiya 63, 1081-1087 (in Russian).

31. Romanenko, L. A., Mikhailov, V. V., Lysenko, A. M. \& Stepanenko, V. I. (1995). A new species of melanin-producing bacteria of the genus Alteromonas. Mikrobiologiya 64, 74-77 (in Russian).

32. Rüger, H.-J. \& Krambeck, H.-J. (1994). Evaluation of the BIOLOG substrate metabolism system for classification of marine bacteria. Syst Appl Microbiol 17, 281-288.

33. Simidu, U., Kita-Tsukamoto, K., Yasumoto, T. \& Yotsu, M. (1990). Taxonomy of four marine bacterial strains that produce tetrodotoxin. Int J Syst Bacteriol 40, 331-336.

34. Smibert, R. M. \& Krieg, N. R. (1994). Phenotypic characterization. In Methods for General and Molecular Bacteriology, pp. 607-654. Edited by F. Gerhardt. Washington, DC: American Society for Microbiology.

35. Svetashev, V. I., Vysotskii, M. V., Ivanova, E. P. \& Mikhailov, V. V. (1995). Cellular fatty acid of Alteromonas species. Syst Appl Microbiol 18, 37-43.

36. Swann, G. A. (1974). Structure, chemistry and biosynthesis of melanins. Fortschr Chem Org Naturst 31, 521-582.

37. Turvey, J. R. \& Christinson, J. (1967). The hydrolysis of algal galactans by enzymes from a Cytophaga species. Biochem $J$ 105, 311-316.

38. Van Landschoot, A. \& De Ley, J. (1983). Intra- and intergeneric similarities of the rRNA cistrons of Alteromonas, Marinomonas (gen. nov.) and some other Gram-negative bacteria. J Gen Microbiol 129, 3057-3074.

39. Voller, A., Bidwell, D. E. \& Bartlett, A. (1979). Setting up ELISA. In The Enzyme-Linked Immunosorbent Assay (ELISA). A Guide with Abstracts of Microplate Applications, pp. 38-39. Guernsey: Dynatech Europe.

40. Wayne, L. G., Brenner, D. J., Colwell, R. R. \& 9 other authors. (1987). International Committee on Systematic Bacteriology. Report of the ad hoc committee on reconciliation of approaches to bacterial systematics. Int J Syst Bacteriol 37, 463-464.

41. Weiner, R. M., Segai, A. M. \& Colwell, R. R. (1985). Characterization of a marine bacterium associated with Crassostrea virginica (the Eastern Oyster). Environ Appl Microbiol 40, 83-90.

42. Yamaura, I., Matsumoto, T., Fumatsu, M., Shigeri, H. \& Shibata, T. (1991). Purification and some properties of agarase from Pseudomonas sp. PT-5. Agric Biol Chem 55, 2531-2536.

43. Yaphe, w. (1957). The use of agarase from Pseudomonas atlantica in the identification of agar in marine algae (Rhodophyceae). Can J Microbiol 3, 987-993. 